\title{
EUTOMIA
}

Revista de Literatura e Linguística

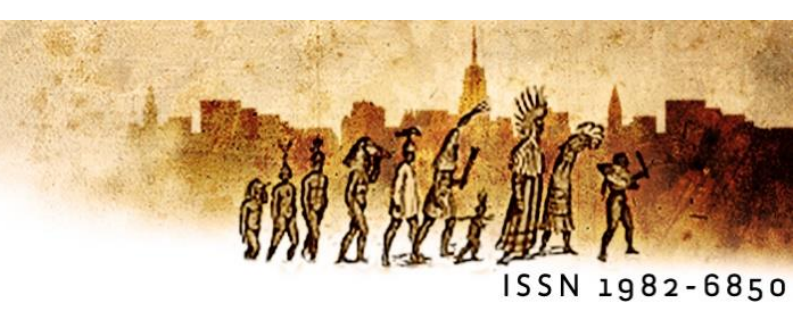

Eunice Boreali

\section{SER POESIA}

algo me sufoca e não tem nada

com esse tempo

esse medo

esse vírus

estou só

mas imune não estou

aos sentidos das humanidades

por isso mesmo branca

também morro com George Lloyd

morro mais ainda com Miguel

morro de saudade dos sonhos Ágatha

Morro e sei que o mundo não vai se acabar por isso

Morro. A humanidade? Não sei.

$*$

Morro de tristeza. Lembro do homem dizendo que amor não é nada disso. Morro de sufoco. Mas ainda tiro as suas mãos da minha garganta. Morro de medo de fazer novo amigo. Morro de medo do amor que não é nada disso. Morro de medo de me abrir, sou fera frágil... Mas não grito. Morro de medo de mostrar e vivo no 
palco. Morro de medo de você não ver quem sou... E o medo tenta falar por mim. E quem sou, de novo, sufocada, tem medo de ouvir dizer que eu não sou nada disso. E agora sou quem me coloca na emboscado. sou agora quem me coloca numa emboscada. Morro. De novo. e ninguém tem nada haver com isso. Morro e mato, mesmo sem saber quando há vida e morte no que digo.

\section{$*$}

te cuida com carinho

mas não brinque assim comigo

digo isso pra ti mas é comigo

que brigo

não fosse a dor melhor seria

viver a presença do alívio

afinal

sorrir de si é o princípio

desse

estar

sendo

mesmo

sem ter

sido

se tecendo

se torcendo

dentro do olhar labirinto

$*$

me perdoe, mas a culpa não é minha

sinto dores abismais

e o meu próprio eu naufraga em mim

deve ser mercúrio retrógrado

Eutomia, Recife, 26(1): 315- 318, Dez. 2020 
ou talvez carma do passado

provavelmente seja do cartório

esse absurdo de escrever

a justiça sem lei

a vitória sem justiça

numa eleição de perdedores

de um país que nunca foi

mas essa culpa sim

é tanto minha quanto sua e de quem nem leu isso aqui

$*$

a culpa até parece

uma tentativa de se aprisionar

na própria ignorância

afinal

entre eu e você

há também a coautoria

algo nos escapa

talvez seja uma outra matemática

outro ecossistema

outra realidade

talvez tudo

probabilidade

Ou a oportunidade de

orquestrar o caos com a poesia

inclusive sua

$\operatorname{sim}$

você, aqui, vivendo toda a leitura.

Eutomia, Recife, 26(1): 315- 318, Dez. 2020 
há tempos me lembrei poeira

e quando morro de tristeza

sinto o oceano por dentro

vida nascente até que

nossa

tal humanidade perturba

então evaporo e voo para renascer

semente em floresta é poesia

tecer meta não é se prender na linha reta

se tecer perceber e depois do ciclo, espiralar

lembra que desejo, movimento

não é ser só

fantasia

fantasma

Falta

Asma

Farta

Ânima

nem o vulto do que se pensa dos pais

muito menos do país

a nação se mente quando não se vê

semente

E a nossa subjetividade é força

delicada

\footnotetext{
' Eunice Boreal é filósofa, produtora e artista. Nasceu em 1984 na capital paraibana. Pratica arte desde os 9 anos e hoje, a partir do seu conceito de Poesia TransForme, desenha, dirige filmes, canta, atua e promove o método com inspirações interdisciplinares. Realiza cursos e palestras há anos. Já recebeu diversos prêmios, realiza projetos e publica em revistas nacionais e internacionais. É a fundadora e diretora geral do Lavip - Laboratório de vivências poéticas.
} 